\title{
Is Bhasan Char Island, Noakhali district in Bangladesh a sustainable place for the relocated Rohingya displaced people? An empirical study
}

\author{
Md Rafiqul Islam ${ }^{1}$ (D) Md Touhidul Islam ${ }^{1} \cdot$ Mohammad Shaheenur Alam $^{1}$. \\ Maria Hussain ${ }^{1}$ - Muhammad Mazedul Haque ${ }^{2}$
}

Received: 19 April 2021 / Accepted: 21 October 2021 / Published online: 22 November 2021

(c) The Author(s), under exclusive licence to Springer Nature Switzerland AG 2021

\begin{abstract}
More than one million forcefully displaced Myanmar nationals, known as Rohingyas, are currently living in the 34 camps in the Cox's Bazar district in Bangladesh. To reduce the pressure of Rohingyas in Cox's Bazar, the government of Bangladesh has started the process of relocating some of the Rohingyas to Bhasan Char Island located in Noakhali district, Bangladesh. However, some international organisations, NGOs, and some people expressed their concerns over this relocation process. This article, thus, offers an evidence-based holistic perspective that explains the available facilities and opportunities that could bring a new hope instead of a threat to Rohingyas. Through a multi-method research approach, the paper argues that the Island is suitable for the displaced Rohingya people. It also explores that the relocation project has opportunities for Rohingyas to engage in some livelihood activities. The Island is stable and livable on a temporary basis and has adequate safety and security measures-embankments, wave breakers, shelter centers, and modern housing facilities-have been undertaken. This article, thus, concludes that Bhasan Char can offer a new hope-not a place with threats, for the Rohingya displaced people, to live temporarily before their repatriation to Myanmar.
\end{abstract}

Keywords Rohingya crisis · Bhasan Char $\cdot$ Relocation $\cdot$ Displaced people

\section{Introduction}

Bangladesh is hosting more than one million displaced Rohingya people living in 34 camps in Ukhiya and Teknaf in the Cox's Bazar district in Bangladesh (Alam 2019). More than 4 years have passed since the mass exodus in 2017 , however, no fruitful

Md Rafiqul Islam

rislampacs@du.ac.bd

https://www.du.ac.bd/faculty/faculty_details/PCE/612

Extended author information available on the last page of the article 
results regarding the resettlement, repatriation, and reintegration of the Rohingya displaced people to their home country have yet to be attained (Jacob 2017; Banerjee 2020). Moreover, the environment in the current camps has been extremely vulnerable and unsustainable for such as a large number of Rohingya displaced people (UNDP 2018). Both manmade and natural disasters such as floods, cyclones, landslides, and the Covid-19 pandemic have caused untold suffering and cost of human lives in the camp areas (Ullah et al. 2020). As a result, the Government of Bangladesh $(\mathrm{GoB})$ has undertaken a number of measures including the construction of the Ashrayan-3 project $^{1}$ in Bhasan Char Island, Noakhali district (Fig. 1) under the banner of 'Refugee Management Approaches'-to better manage the refugees with adequate facilities and security measures.

The government has planned to relocate some of the Rohingyas to reduce the population pressure and environmental destruction in the current locations in Cox's Bazar. Under this project the GoB plans to relocate some 100,000 Rohingya displaced people from the current camps to Bhasan Char-a 13,000 acre Island located in Hatiya upazila of Noakhali District in Bangladesh (Humanitarian Response 2020). The Bhasan Char Island is now inhabited by around 20,000 Rohingya displaced people relocated by the government of Bangladesh since December 2021 (The Daily Star 2021) as well as some local Bangladeshi people-who are living there for business purposes and cattle rearing. Before the construction of the Ashrayan-3 project, the Island was not inhabited, but some cattle breeders, fishermen, and Bangladesh Navy security forces previously lived there temporarily.

Bhasan Char, an Island that originated around twenty years ago, ${ }^{2}$ is located approximately 28 nautical miles from Chittagong and 13 nautical miles from Hatiya, and around 4 nautical miles from the nearest Island Sandwip (Banerjee 2020). The 'Ashrayan-3 project' consists of 120 housing plots including 120 cyclone centers, solar systems, water sources, roads for internal communication, mobile phone networks, and a 9-foot high flood protection embankment (Illius 2019). This project also contains adequate health facilities, temporary work, and livelihood opportunities and, formal and informal education facilities for Rohingya children to make this Island livable (The Daily Star 2020). This location is often named the minitown, however, various hurdles have prolonged and hindered the relocation project. Reports from some sources (e.g. in newspapers, TV, or International Non-governmental Organization (INGO) reports) have portrayed the Island as uninhabitable and unfit for the Rohingya displaced people to live in (Amnesty International 2020; Deutsche Welle 2020). The United Nations and Amnesty International urged an independent assessment of the habitability of Bhasan Char, following their reported accounts of Rohingya displaced people supposedly being relocated against their

\footnotetext{
1 Ashrayan-3 project is constructed to shelter more than a 100,000 Rohingya displaced people temporarily. Ashrayan is a Bengali term which refers to giving shelter to anyone. In keeping this in mind, the project has been named as Ashrayan-3 project in Bhasan Char.

2 Bhasan Char, also known as 'Char Piya' and 'Thengar Char' is an Island in Hatiya Upazila, Bangladesh. This Island was formed in 2000 but inundated. In 2006 this Island again emerged and is gradually increasing in size.
} 
informed consent (Reliefweb 2020). Thus, this topic demands scholarly attention and investigation to assess the livability, viability, and longevity of the Island.

Within this context, this article aims to assess the suitability, livable condition, and sustainability of living in the Ashrayan-3 project. This article examines the question of whether the Ashrayan-3 project is a sustainable place for living for the relocated Rohingya displaced people. To answer this research question, a mixed approach combining interviews, focus group discussions, and participant observations has been applied to investigate the location, availability of livelihood, security issues, and other human rights concerns. The article first provides a short background of the Rohingya repression and forceful displacement to Bangladesh. Secondly, this article provides a theoretical framework of sustainable living based on livelihood, security (both physical security of the place and individual security), and human rights literature. This is followed by a detailed outline of the methodology of data collection, data analysis, and data presentation. The fourth section provides the findings and discussion of the data following the theoretical framework. Finally, the paper concludes with comments on the prospect of the Bhasan Char project with some observations on further initiatives that need to be undertaken to make this place a sustainable living location.

\section{Contextual study: Rohingya displacement and relocation issue}

The Rohingya displaced people, originating from Myanmar, are one of the most oppressed populations in the world, and have been the subject of extensive persecution and human rights violations (Islam 2020; Ullah and Chattoraj 2018). Literature suggests that the origin of the predominantly Muslim Rohingya people in Myanmar is contested, as the Myanmar Buddhist community identifies them as the descendants of immigrants from the Chittagong District of Bangladesh; however, Muslim historians claim that Rohingyas have been living in the country for more than 1000 years (Bremner 2020). The long-standing repression by the military regime and deprivation of citizenship rights (Ullah 2011; Albert and Maizland 2020), have equally forced the Rohingya people to flee to other countries, and a significant number of them have taken shelter at Cox's Bazar, Bangladesh (Alam 2019).

The primary influx of Rohingyas to Bangladesh started in 1978, with a large arrival in 1991-1992 (Ullah and Chattoraj 2018). Currently, these people are living in the official camps managed by the United Nations High Commissioner for Refugees (UNHCR) in Cox's Bazar, Bangladesh. The recent Rohingya influx to Bangladesh started on 25 August 2017 with the arrival of an estimated 537,000 Rohingyas across the border from Myanmar into Cox's Bazar (Alam 2019). According to the UNHCR, around 8,69,994 forced migrants came to Bangladesh from Myanmar over different periods where only 33,784 are registered (only 4\%) and the remaining 836,210 are treated as forcibly displaced people by the Government of Bangladesh (UNHCR 2018). These people now have to depend on humanitarian assistance from the Government and different local and international NGOs (ISCG 2017).

In August 2017, an estimated 745,000 Rohingyas entered Bangladesh and are now living in about 33 camps in the Cox's Bazar district (Uddin 2019). They are 


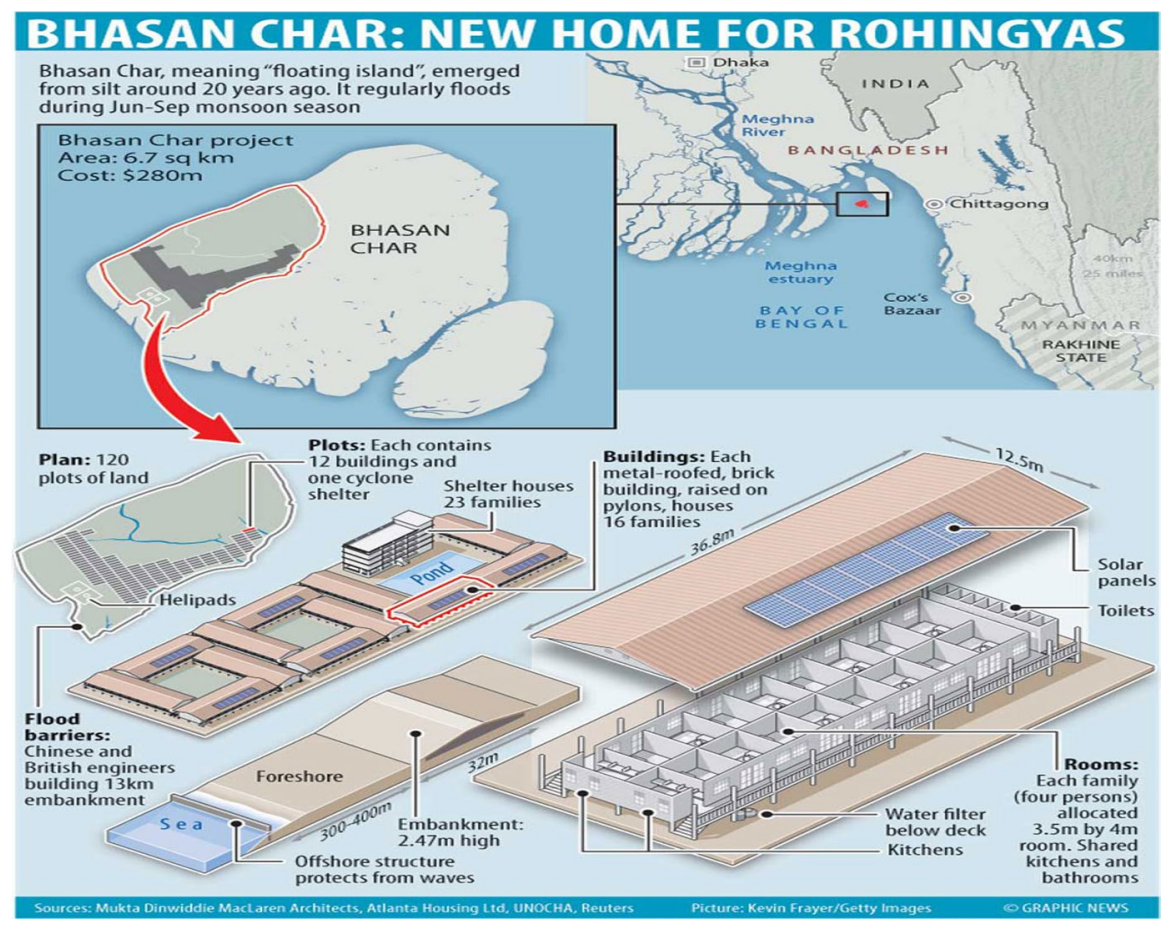

Fig. 1 The location of the Bhasan char Island ( Source: Reuters)

now in the makeshift camps developed for them by the GoB and international organizations working to facilitate their temporary shelter in Bangladesh. The current condition in the camps at Cox's Bazar has, thus, become increasingly cramped and insecure. This has made the response of the GoB to provide necessary humanitarian assistance increasingly critical. The dense population of the Rohingya displaced people has also caused environmental degradation in the camp and nearby areas as natural resources have been depleted and degraded (Ahmed 2020).

Meanwhile, the local conditions, socio-cultural environment, and natural ecosystem of the region have suffered serious decline, because of the growing influx of the Rohingya population in Bangladesh (UNDP 2018). The local people have started to become frustrated due to cohabitation problems with the nearby Rohingya displaced population in the camps. Various crimes and unlawful activities inside and outside the camps have seriously increased, undermining the social peace and harmony of the region (Mallick 2020). Therefore, the issue of Rohingya displaced people has been a serious matter of concern in terms of social stability, security, and the economy of the region and Bangladesh as a whole. Despite the efforts of the international community, the Bangladesh government is struggling to manage a large number of Rohingya displaced people. The position of Cox's Bazar in terms of strategy and tourism has come under threat due to environmental degradation, social disorder, and overall chaos. Therefore, the issue of relocation of some of the Rohingya people from Cox's Bazar to other locations including the Bhasan Char has emerged. 
However, relocation of the Rohingya displaced people from Cox's Bazar to other locations needs to be based on proper investigation and should follow the principles of sustainable living. This investigation of the sustainability of living of the displaced people occupies an important consideration in the context of their relocation. This article explores the issue of sustainability of the living of the displaced people in Bhasan Char where the government of Bangladesh has taken the policy of relocation of the Rohingya displaced people.

\section{Conceptual ideas}

The Rohingya displaced people living in Bangladesh badly need their livelihood, security, assurance of human rights, and sustainable living. Therefore, the four fundamental conceptual issues-sustainability, livelihood, security, and human rights-in the Ashrayan-3 project are examined. These concepts are not new, but well-founded by the international community and multi-states organizations such as the United Nations.

\section{Sustainability}

Sustainability as a term denotes different meanings in different disciplines. This concept is connected to the economic and environmental issues-sustainable development and environmental sustainability. The Brundtland Commission report coined this term to sensitize the international community to the effects of development efforts on the environment and future human lives (WCED 1987). The World Bank later developed this idea by triangulating the three interlinking issues-economic, ecological, and social dimensions-which delineates the idea of sustainability as an opportunity "to leave future generations as many opportunities as we ourselves have had, if not more" (Koning 2001, p. 68). Gradually, the term social sustainability emerged for qualifying the economic and environmental dimensions of social living, promotion of social capital, participation, and capacity building of the citizen (Colantonio 2009). Social sustainability also included the issues of employment, poverty alleviation, happiness, and social connection as its core elements. More recently, some fundamental aspects of human development, such as education, skills, experience, consumption, income, and employment have also been referred to by this concept (Omann and Spangenberg 2002). In sum, the concept of social sustainability is a comprehensive term that covers many aspects including livelihood, security, and human rights for all people. Social sustainability for the refugee and forcibly displaced people would denote ensuring livelihood, security, human rights, and other fundamental rights. 


\section{Livelihood}

Ensuring livelihood is the core component of the concept of social sustainability and human rights. Livelihood means the distribution of assets and power so that people can lead their lives. Chambers and Conway (1991) used the term sustainable livelihood as denoting the capabilities and assets of people to sustain themselves. International organizations such as CARE (i.e., the Cooperative for Assistance and Relief Everywhere), UNDP (i.e., the United Nations Development Programme), and Oxfam used the livelihood approach to ensure people's access to resources and capabilities to reduce their poverty, recover from stresses and ensure healthy lives (Haidar 2009). In a broader perspective, livelihood is connected with three interlinking aspects, such as assets, context, and strategies. Assets enable people to pursue their goals and reduce poverty (Li et al. 2020). Context, such as economic trends, and different types of shocks and seasonal influences (availability and scarcity), also determine people's livelihood. The third pillar of livelihood is the strategy that refers to the activities of the people to achieve their livelihood goals (Haidar 2009).

In the case of forced migrants and displaced people such as the Rohingyas, livelihood approaches carry different meanings as they lose everything including assets, family members, and community relationships, even emotional and physical health. In such a condition, the migrants and displaced people depend on the support of the aid agencies and host governments to fulfill their livelihoods (Jacobsen 2014). Forced migrants and displaced people are often unable to utilize their efficiency and human capital, such as skills and experiences that they gained or practiced in their home countries. This is largely because they are most likely not given permission to work, or even if they do work, they commonly face discrimination at the workplace as well. Community development allows the refugee people to build the capacity to face their challenges and regain their lost positions (Calhoun 2010). In sum, livelihood constitutes the core elements of sustainable living for the displaced and migrant people as they need livelihood options for their survival.

\section{Security}

Security is another key component of sustainable living for the displaced and migrant people (for example, Rohingya displaced people) as they have nothing to protect themselves. In the context of sustainable living, security does not mean the military capability of a state but refers to the non-traditional security issue that ensures human potential and development (Srikanth 2014). The writing of Buzan and Hansen widened the concept of security by adding five sectors of security-military, regime, societal, environmental, and economic security-to cover all concerning aspects of human security (Buzan and Hansen 2010). However, the addition of human security to the lexicon of security concept by the UNDP Human Development Report grounded the two fundamental issues-freedom from fear and want-as the core issues of security (UNDP 2005). Freedom from fear means emancipation from any kind of repression, persecution, killing, intimidation, and torture. On the other hand, freedom from want is more akin to ensuring basic human needs at any 
time irrespective of any distinctions based on race, ethnicity, and religion, and so on. In their discussion of refugee and forced migration, governments across the world have tightened the immigration process and taken various measures for the protection of migrant and displaced people within the charter of international norms and treaties (Hammerstad 2014). The influx of forced migration and displacement across the world is putting pressure on host countries and international organizations to ensure their safety and security.

\section{Human rights}

Ensuring human rights by the host place and international community also constitutes a fundamental issue for ensuring the social sustainability of the migrants and forcibly displaced people. Human rights in this context mean the inalienable and indispensable rights of the human being. The Universal Declaration of Human Rights (UDHR) in 1948, International Covenant on Civil and Political Rights (ICCPR) 1966, and International Covenant on Economic, Social and Cultural Rights (ICESCR) 1966, guaranteed a comprehensive list of rights as human rights (Majodina 2009). Under these categories, human rights are those rights that a human being enjoys because he/she is a human being. Although the UDHR prescribed a comprehensive list of rights for all human beings in the world, the increasing rate of refugees and forcibly displaced people demanded special protections from the host country as well as the international community. Thus, the 1951 Refugee Convention was enacted providing a comprehensive list of rights and privileges of displaced and refugee people (Weis 1995). Among the list of the rights of refugees, the refugee conventions prescribed the rights of non-refoulement, no torture, and no inhuman and degrading treatment or punishment (Majodina 2009). The convention gave emphasis to the right to life and physical integrity to protect human lives.

Therefore, the host country and international community must take affirmative measures to prevent any sort of arbitrary killings or other mistreatment of the displaced and refugee people. The displaced and refugee people require, as all human beings, the right to freedom of movement, livelihood, employment, and development. Forced migrants and displaced people are also entitled to enjoy the full range of civil, political, economic, social, and cultural rights set out in international and regional human rights treaties and customary international law. With very few exceptions, such as practicing the right to vote, the right to stand for public office, and the expulsion of aliens, the international human rights instruments make few distinctions between the rights of citizens and forced migrants (McAdam 2014).

The above conceptual ideas reflect that these concepts have been used separately but they are closely connected and often used as cross-cutting approaches. Livelihood, safety, security, and sustainability are widely regarded as human rights of all people, thus it can be broadly termed as the social sustainability framework. Based on these concepts, a framework (Fig. 2) has been developed that covers the protection of the Rohingya displaced people. The framework has been developed to advance the analysis and presentation of the data collected for this study. 
The first part of this framework is sustainability and livability. The finding section analyses the sustainability and livability of the Bhasan Char Island for the Rohingya displaced people. The second part is livelihood which has been used to see what opportunities are available in Bhasan Char. The third component-safety and security-has been used to assess the protection mechanism and available security measures in Bhasan Char so that the relocated Rohingya people can live in safe and safety. Finally, the last part of the framework is the issues of human rights which have been used to explore the condition of ensuring human rights items the relocated people will enjoy after relocation.

\section{Methodology}

A qualitative interpretive approach with multiple methods-(i) focus group discussions (FGDs) with relevant stakeholders in Bhasan Char, (ii) key informant interviews (KIIs) with influential local stakeholders, (iii) expert interviews (EIs) with different professionals who visited Bhasan Char and observed the Island and its sustainability, and (iv) direct observation (DO)-were used as research methodologies in this study. A qualitative interpretive approach enables the researchers to construct knowledge from the analysis and interpretations of the research participant's perceptions and experiences (Woodyatt et al. 2016).

\section{Research participants}

The researchers (five authors) actively participated in all sections of this research project-protocol development, pilot study, data collection, analysis, and presentation. The research team visited Bhasan Char twice: first in November 2020, then in February 2021. Before going to the field, the researchers sought permission from the concerned authority as the Bangladesh Navy supervised the Ashrayan-3 project. The researchers also sought permission for the entrance of three experts (three university professors-a sociologist, a geologist and disasters science expert, and security expert) who accompanied the researchers to get firsthand experience about Bhasan Char Island and shared their observation and understanding about Bhasan Char and relocation of the Rohingya people.

\section{Interview protocols and ethical issues}

Before the field data collection, the researchers conducted an extensive literature review, including books, journals, publicly available policy documents, and newspapers regarding Rohingyas' issues and Bhasan Char. The literature review enabled the researchers to develop research instruments such as semi-structured questions for FGDs, KIIs, and EIs (See Table 1).

The research team developed an open-ended question guide to cover the areas of expertise of each interviewee to be used by the EIs. The research team also prepared the FGD guiding questions and themes and the KIIs questions in accordance with 


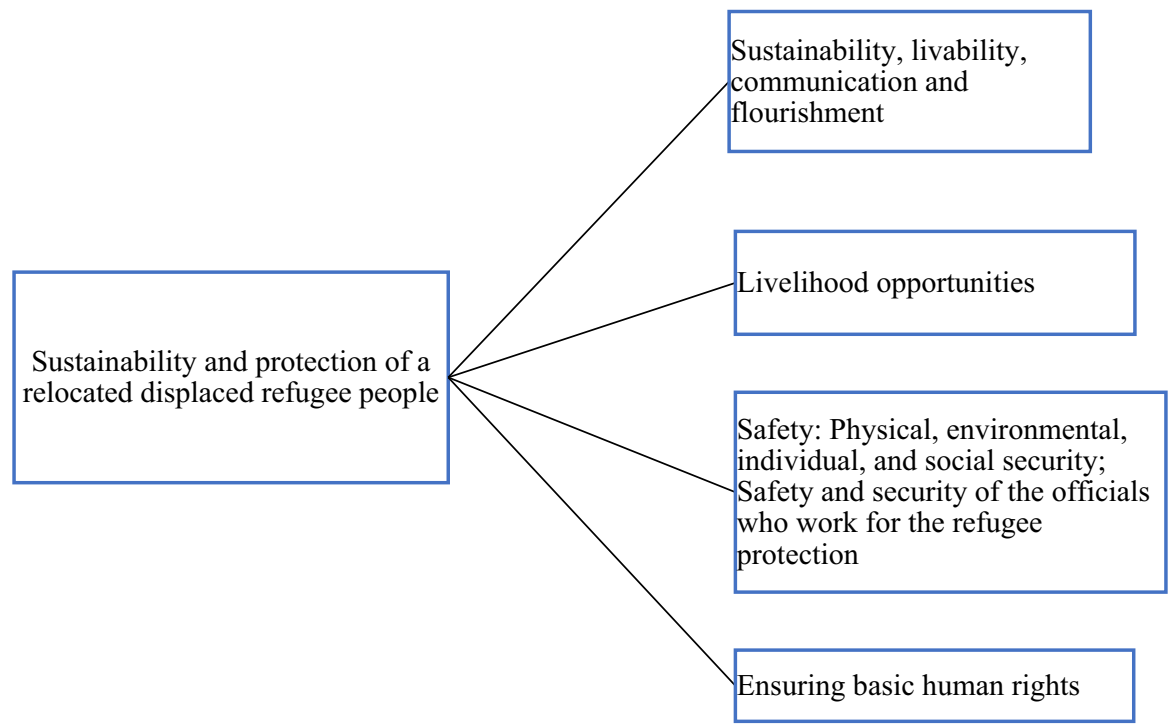

Fig. 2 Theoretical framework ( source: developed by the authors)

the research objectives and themes set in the theoretical framework. To avoid the language barrier in the field, the research team appointed research assistants, including two local people, who understood the local dialects of the greater Chittagong region.

The study considered the appropriate human ethical issues. As there is no formal ethics approval system in Social and Behavioral science in Bangladesh, the research team sought permission from the research participants before conducting the interviews. The research team presented a consent form to the participants and informed them that their participation in this project was voluntary. The research team also followed the principle of anonymity and confidentiality which constitutes a vital part of social research (Wiles et al. 2008).

\section{Data collection}

The researchers collected considerable data using the above methods. Data were collected from FGDs as this method allowed the participants to reflect on the issues they discuss and thus bring critical knowledge to the research (Woodyatt et al. 2016). This study conducted four FGDs-two FGDs involved the local Bengali people and two with the relocated Rohingya people in Bhasan Char-who were selected purposively. The participants were Bengali shepherds and buffalo herders, and shopkeepers at the local market. They were people who came from adjacent areas like Noakhali and had access to Bhasan Char. As they had firsthand experience about the Island, their knowledge and opinions were vital to understanding various aspects of livelihoods, safety and security, and sustainability of the Island. The research team 
Table 1 An overview of data collection participants

\begin{tabular}{lllll}
\hline Fieldwork periods & Methods & Number & Male & Female \\
\hline November18-19, 2020; & Key informant interview & 8 & 6 & 2 \\
& Focus group discussion & 4 focus group (In each group & 3 & 1 \\
& & 6-10 participants attended) & & 1 \\
\hline
\end{tabular}

conducted another two FGDs among the Rohingya people when they were relocated in Bhasan Char. The aim of the FGDs was to get the perception and experience of living in the houses developed for the refugees on the Island. The opinions and experience of these relocated Rohingyas enabled the researchers to grasp the real issues of living, livelihood, and rights in Bhasan Char. Interviewees were selected purposively, and local gatekeepers helped the research team access and conduct FGDs. Two research assistants who understand Rohingya dialects helped in the conduct of FGDs with Rohingya stakeholders and translated and transcribed data.

The researchers also conducted eight key informant interviews-four KIIs on 18-19 November 2020, and another four on 9-10 February 2021. The first group of informants was officials who worked closely with the Ashrayan-3 project and officers who monitored the project activities and progress. They worked on the development of the project and developed knowledge about the Island and its adjacent areas and associated challenges and opportunities. Thus, these interviews provided local knowledge, information, and problems associated with Bhasan Char and the Ashrayan-3 project. The other four KIIs were conducted with Rohingyas e.g. Majhis, a block leader, an imam, and a teacher. They were selected as they had reasonable control and connections with ordinary Rohingyas living in cluster houses in Bhasan Char. They shared their experience of living in the Ashrayan-3 project area after their relocation to Bhasan Char. They also shared information about the living conditions, opportunities, challenges, and expectations on the Island.

The researchers interviewed five experts in the relevant fields. In social research, interviews with experts assist a research process to gain and explore contextual, implicit knowledge of a social issue (Döringer 2020). Among the experts, the three who visited Bhasan Char with the researchers have a broader understanding of socio-political issues, sociology and human rights, geology, and disaster science, and security matters. These experts were intentionally chosen for their significant knowledge and understanding of the subject. Immediately after they saw the Ashrayan-3 project and Bhasan Char, they provided their observations, insights, and shared thoughts on the subject aspects of this research. The other two experts were interviewed later at Dhaka. One of them was a geologist who has expertise in Island formation and underground water resources, while the other is an expert on disaster science and management who has a particular interest in Bhasan Char, its formation, and sustainability. They also offered information based on their independent assessments of Bhasan Char and its sustainability and shared their opinions concerning the livability and habitability of Rohingyas in the Ashrayan-3 project. 
The researchers visited Bhasan Char and directly observed the Ashrayan-3 project area and the available facilities for the relocated Rohingyas who live there. These observations provided first-hand experience of seeing the facilities. The researcher's and experts' overall visit and observation enabled them to validate the data that various FGDs and KIIs had shared with them Researchers also talked informally with the local people beyond the scheduled interviews and FGDs, which allowed verification of some crucial data gathered through other methods.

Data generated through these combined methods helped the researchers to understand various aspects of Bhasan Char and the relocated Rohingyas living in the Ashrayan-3 project. Various critical issues and challenges of actual scenarios in the study area also emerged. Once data were collected the researchers undertook a thematic analytical process. Data were sorted and coded as per the themes and were analysed by the inductive method, mixing with narrative discussion and critical explanation.

\section{Major findings}

Data have been presented in the areas of safety and sustainability, water and sanitation, livelihood opportunities, security, and other physical opportunities that would enable the displaced people and supporting staff to live secure and safe lives.

\section{Safety and sustainability}

This study explored information about safety and sustainability from multiple sources such as KIIs, FGDs, and EIs. Before exploring the opinions of the stakeholders, this study asked the experts about the safety and sustainability of the Island. The experts shared their opinions that there is no chance of the Island being washed away due to severe floods and cyclones. The professor of Disaster Science and Management, University of Dhaka argued that,

Only a powerful tsunami would be able to enter and do any sort of flooding and damage, which hasn't been recorded yet in this area. In the extreme conditions of high-level signals like that of a level 8 to 10 warning, the relocated Rohingyas only have to move to the shelters on an emergency basis, till the calamity subsides.

Further "the Island is growing gradually. In the Meghna estuary, 1.6 trillion tons of sedimentation is deposited per year. This deposition of sedimentation is helping to increase the Island." In relation to comments on the risks of damage from cyclones, he added that "No reported cyclone has damaged the Island in the last 200 years." This information confirms that the Island is stable and sustainable for living. In discussing the Island's sustainability against land-based disasters such as earthquakes, another expert in the field of Geology noted that, 
Evaluating 200 to 300 years of earthquake records it can be said that the Island is stable, because there is no evidence of inundation and destruction of Islands in this area due to the earthquakes.

The key informant-who has been responsible for constructing the project, gave his opinion about the viability and stability of the Island stating that "We have plans here to build more species of mangrove plants, so that erosion does not take place."” In addition, he pointed out that "construction work for a 19 feet dam for handling tidal waves is underway which will protect the Island from any forms of cyclone and flood". ${ }^{4}$ A Geologist and Disaster expert of the University of Dhaka also added that,

The Island is stable, and is somewhat going towards stability. Now, this construction work happening in Bhasan Char has started since December 2017. Due to this, they have noticed the side of the Island where erosion takes place, and they've installed wave breakers and undertaken various artificial measures on that side. The erosion has been prevented with such measures.

It was also observed that there is adequate preparation for protecting the Island and its people from natural disasters and environmental risks. In Bhasan Char, there are 120 clusters houses and 120 cyclone shelters, and every shelter has the capacity to accommodate more than 1000 people (Fig. 3).

The sources confirm that there is no such arrangement to face such disaster in the other coastal areas in Bangladesh. ${ }^{5}$ Thus, the sociologist who accompanied the research team argued that this is a mini-town with high quality infrastructure, which is rare in other char lands (other Islands) in Bangladesh. ${ }^{6}$

While asking about the impacts of recent past disasters, a key informant pointed out that "there has been no significant impact here from the recent disasters, namely 'Bulbul' ${ }^{7}$ and 'Amphan'. ${ }^{8}$ The FGDs participants also shared their views about disasters and their impacts on the Island arguing that "Alhamdulillah, ${ }^{9}$ although there has been a lot of damage across the country during the cyclone Amphan, very little damage had happened here". ${ }^{10}$ Some of the participants particularly mentioned that "the embankment constructed here is mighty and there is no such place safer than

\footnotetext{
3 18/11/2020, Key Informant Interview taken at Bhasan Char, Hatiya, Bangladesh.

${ }^{4}$ Ibid.

${ }^{5}$ As evidenced by the nearby Island Hatiya having its embankment collapse in 21 August 2020, from 25 villages flooded after COLLAPSING Embankment in Hatiya. (2020, August 21). Retrieved from https:// www.risingbd.com/english/country/news/73325 (Accessed on February 08, 2021).

${ }^{6}$ 18/11/2020, Expert Interview taken at Bhasan Char, Hatiya, Bangladesh.

${ }^{7}$ Bulbul was a strong tropical cyclone which struck the Indian state of West Bengal, and Bangladesh, occurring in November of 2019. It caused strong storm surges, heavy rainfall, and flash floods across the affected areas. Source: Reliefweb.

${ }^{8}$ Amphan was a massively powerful tropical cyclone that caused widespread damage and catastrophe in Eastern India, specifically West Bengal, Odisha, and in Bangladesh, occurring in May of 2020. Source: Reliefweb.

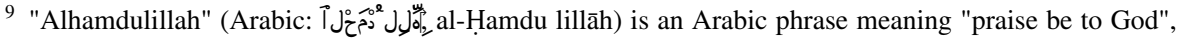
sometimes translated as "thank God".

10 18/11/2020, Focus Group Discussion taken at the Bazar, Bhasan Char, Bangladesh.
} 
this". ${ }^{11}$ Another participant agreed and added that "there is no such an embankment in Hatiya, so the area might get flooded there. But here, they have built the embankment to be very capable and sturdy for handling floods." 12 The Project Director also shared that "the wave breakers have been installed to weaken the waves. Then at the second stage, there are the low elevated barriers, built with gravel, and geo-bags filled with sand. When the waves hit this barrier, they become even further weaker. This three-layered engineered protection system further lowers the intensity of the waves, so that when they hit the embankment, they become even weaker."13

Considering all the information from the various sources, it can be argued that Bhasan Char Island is sustainable, viable, and secure for living. With regards to the Island weather conditions, the geologist and Professor of Dhaka University commented that the weather conditions of Bhasan Char would be perfect for human living. The weather is normally conducive to good living as there is no extreme hot or extreme cold. Consequently, living in Bhasan Char would be a good option for the relocated Rohingya people. ${ }^{14}$

\section{Water and sanitation}

Availability of freshwater is a must for sustainable living. As Bhasan Char is an isolated Island, apprehension has been raised about the availability of freshwater (UNHCR 2020). This study asked the project directors and geologists about the presence of groundwater on the Island. The project director argued that in Bhasan Char, water and sanitation facilities are incorporated in the Ashrayan-3 project itself (Fig. 4). ${ }^{15}$

While asking a question about the groundwater availability on the Island, the expert in the field of Environment and Disaster Sciences who visited the Island noted that,

There is an underwater layer of freshwater 700-780 feet deep...They will be able to use this reserve water for domestic use. And since there's a lot of rainfall, measures have been taken so that they can collect and store this rainwater. I hope that this reserve is connected to the mainland, as information on the size of the reserve is not available yet. If it's not connected to the mainland, the water reserve might run dry with extensive use. ${ }^{16}$

Another Professor in the Department of Geology, University of Dhaka has revealed information regarding the nature of the water reserve of Bhasan Char Island. He stated that "Supposedly 5 million cubic meter of freshwater is stored in this Island. Underground aquifers may be available within $200 \mathrm{~m}$ (roughly 700 feet) of land on

\footnotetext{
11 Ibid.

12 Ibid.

13 19/11/2020. Key informant interview taken at Bhasan Char, Hatiya, Bangladesh.

14 02/2021, Expert Interview taken at the University of Dhaka, Bangladesh.

15 18/11/2020, Key Informant interview taken at Bhasan Char, Hatiya, Bangladesh.

16 19/11/2020, Expert Interview taken at Bay of Bengal, Bangladesh.
} 


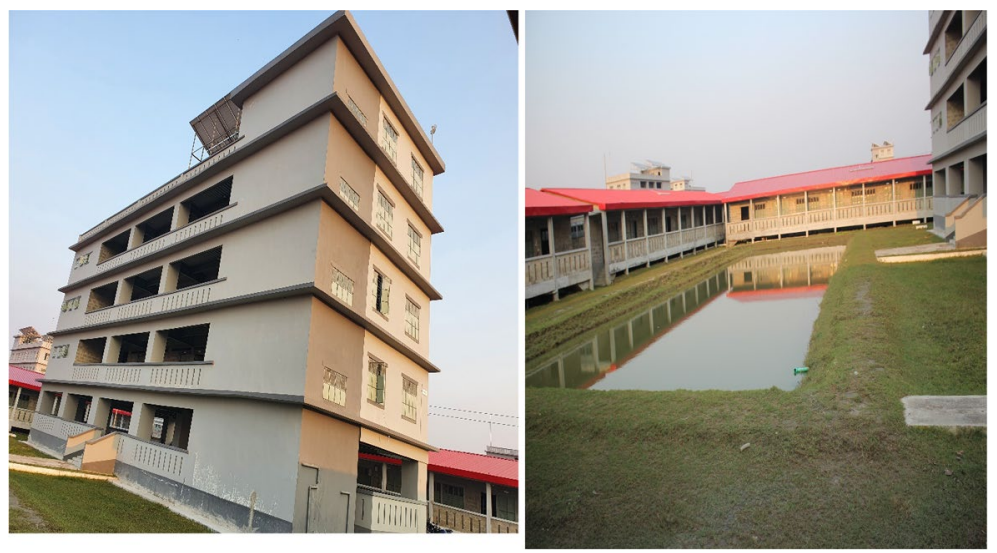

Fig. 3 Cyclone shelter center and housing. Source: Photo taken by the research team

this Island. In coastal areas, the water may be available around 150-200 m underground. In the coastal area, water is reserved as a 'fully confined area' which is called a fully confined aquifer. ${ }^{17}$

Thus, the experts suggested storage of rainwater for use all year round, as depending solely on the aquifer (i.e. the underground water reserve) might deplete it quite rapidly. Our observations in Bhasan Char indicate adequate and modern utility facilities. There are arrangements for meeting the water needs of the people. The project has built a reservoir in each of the houses, and they will be able to store water in those tanks. ${ }^{18}$ Storing and preserving water under each house, and the groundwater supply would meet the needs of freshwater of the relocated Rohingya people in Bhasan Char. While asking the Rohingya people who have been relocated there, about the water and sanitation issues, they argued that they do not face any problems with water and sanitation. Rather, they are very happy to get such good sanitation, water supply, and toilets. ${ }^{19}$ The observations from the study also confirmed the presence of separate toilets and good sanitation systems for the displaced people. Moreover, the displaced people could have the scope to arrange their own toilets with the help of the supporting NGOs as there are lots of open spaces available in the Island.

The drainage system is built keeping waste management in mind. There would be a lot of accumulated waste here as 100 thousand people would be living here together, creating a large amount of waste that would be dumped in one location. A landfill has been designated for this dumping. The project director noted that a 'Green Waste Management System' would be utilized to turn the accumulated waste into suitable compost for reuse." 20 Observation from the study also confirms the

17 02/2021, Expert Interview taken at the University of Dhaka, Bangladesh.

18 19/11/2020, Expert Interview taken at Bay of Bengal, Bangladesh.

19 09/02/2021, Focus Group Discussion taken at Bhasan Char, Hatiya, Bangladesh.

20 18/11/2020, Key Informant interview taken at Bhasan Char, Hatiya, Bangladesh. 

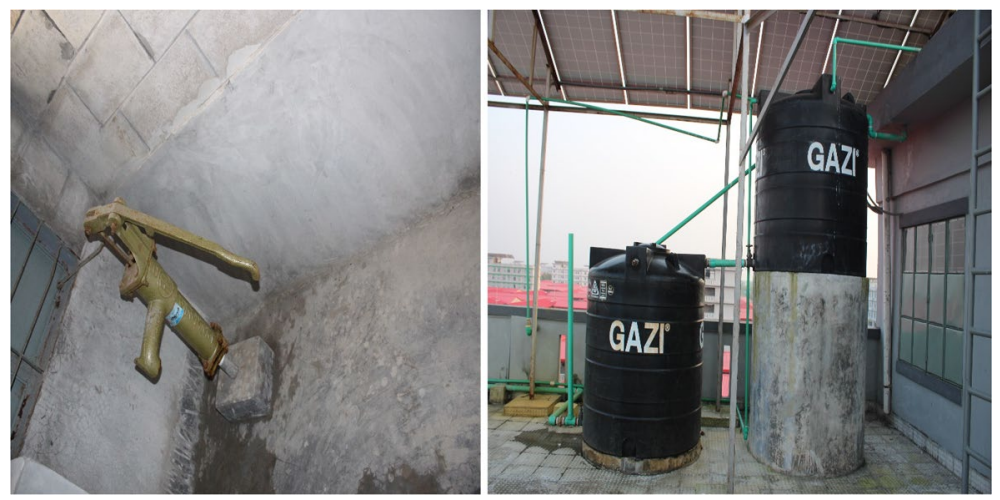

Fig. 4 Available water and sanitation facilities. Source: Photos taken by the research team

construction of planned canals for the drainage system and a landfill site under construction in the project location.

\section{Security system}

The security issues in Bhasan Char have been explored from the KI, participants of the FGD, and subject experts. The participants of the FGD showed their satisfaction about the Island as there is no robbery, insecurity, and piracy in the area. They stated that compared to any other areas of Bangladesh, Bhasan Char is safe. ${ }^{21}$ The authority has taken adequate measures in setting police camps close to the Ashrayan-3 project area to maintain security. While collecting data in the field the study found that two police stations have already been established in the Island to sufficiently cover and protect the population and the distinct nature of its township in Bhasan Char. Another key informant stated that, "We frequently patrol in small squads in order to keep the area under our observations, and to make sure that the Rohingyas do not leave the premises. There is no curfew here." ${ }^{22}$ In response to a question of maintaining security the officer in charge of security explained that, "They resolve every small-scale conflict that happens within and between groups. There are 30 from the police forces, 31 from the Armed Police Battalion Units (APBNs), and 10 female members dedicated to meet the security needs of this area to maintain security system in this area." 23 The participants of the FGD also noted that "there is always a Navy ship, and two Navy boats are stationed here. There's no tendency of crime from the local people. No political activity occurs here." 24

\footnotetext{
21 18/11/2020, Focus Group Discussion taken at the grazing areas near the Ashrayan-3 project site at Bhasan Char, Bangladesh.

22 18/11/2020, Key Informant Interview taken at Bhasan Char, Hatiya, Bangladesh.

23 Ibid.

24 18/11/2020, Focus Group Discussion taken at the grazing areas near the Ashrayan-3 project site at Bhasan Char, Bangladesh.
} 
Indeed, the Island would be a safe place for the Rohingya people to live peacefully. The security expert and Professor of International Relations, University of Dhaka argued that, "Rohingyas are the most vulnerable people and have been traumatized due to the persecution by the Myanmar armies. This arrangement in the Bhasan Char will be a perfect place to live temporarily until their repatriation to their country of origin. Moreover, the relocation to a secure and isolated place would reduce the intra-conflicts as well as prevent the killings of innocent people. ${ }^{25}$

\section{Medical facilities, emergencies, and humanitarian responses}

The study explored the four community clinics and two hospitals, with facilities in place for the treatment of even some serious illnesses, which have been built in Bhasan Char (Fig. 5). There are accommodation facilities for doctors who will be treating the patients in that they have quarters for living with their families. Moreover, pharmacies and space for stored medicines in the hospitals and community clinics have been arranged for the Rohingya displaced people.

As the Island is situated far from the mainland, adequate facilities have been arranged for people who would reside on the Island as temporary settlers. While asking the Project Director about the medical facilities, he argued that,

There is no compromise with the medical services for the Rohingya displaced people in Bhasan Char. Hospitals, clinics and accommodation for the doctors are high in standards. The local doctors and international humanitarian response people will get better places to live in and look after the displaced people.

In response to a question about the medical facilities, the participants in the FGD showed their satisfaction about the medical facilities and medicines. In case of emergency, there is also a scope to take the patient to the city centers for better treatment. One participant mentioned that "he has been taken to Noakhali to better treat him in his legs". ${ }^{26}$ A professor of Sociology, University of Dhaka also gave a satisfactory opinion about the facilities available in the Ashrayan-3 project. ${ }^{27}$ However, there has been some mild dissent regarding the medical facilities received in the month the research team visited Bhasan Char in 2021. The observation also confirms that two helipads and helicopter facilities will enable the expert doctors and humanitarian services to be brought in case of emergencies. Keeping in mind the nature of isolation, the project area is equipped with all necessary facilities to ensure humanitarian responses.

\footnotetext{
25 19/11/2020, Expert Interview taken on a Navy cruiser, at the Bay of Bengal, Bangladesh.

26 09/02/2020, Focus Group Discussion taken at Bhasan Char, Hatiya, Bangladesh.

27 18/11/2020, Expert interview taken at Bhasan Char, Hatiya, Bangladesh.
} 


\section{Livelihood, education, and income opportunities}

One of the key aspects of managing refugees and displaced people is to provide livelihoods and basic human rights (for example, education and income). Keeping this in mind, the GOB has built schools for relocated Rohingya children. Two schools with four-storey buildings have been constructed for the children, who would live on the Island. There are other non-formal structures dedicated to initial learning centers, where teachers will teach children Burmese, English and Arabic. ${ }^{28}$

Employment opportunities for the displaced people mainly consist of being engaged in the agricultural and poultry sectors. The study observed that there are various opportunities to get involved in employment such as through rearing cattle and agriculture (Fig. 6). Through FGDs with the local people in Bhasan Char, the study explored that people have the chance of rearing cattle on the Island and catching fish in ponds and lakes. The participants also pointed out that they collect milk from buffalos and sell it in the nearby markets, therefore, relocated people could use milk for their daily needs.

The Rohingya people mainly depend on rations provided by the NGOs and UNHCR. A key informant pointed out that the relocated people would be able to diversify their livelihood options by engaging with some other activities such as cottage industries. The project director of the Ashrayan-3 project explained that "as this is an Island, there is an immense opportunity to set up an export-oriented foodstuff processing system, where they could work and would produce products during their temporary relocation period in the Island". ${ }^{29}$

While asking about the scope of agriculture another key informant highlighted the potential range and opportunities for food production in Bhasan Char. He argued that there is a scope to cultivate prawns as this is possible using the tide patterns of the Island. There would be more opportunities for cultivating paddy, and other crops in the near future. ${ }^{30}$

\section{Freedom of movement and religious practices}

The project coordinator explained that relocated Rohingya people will enjoy freedom of movement. This study verified this issue of freedom of movement by asking about this at the focus group. The FGD participants mentioned that they can move anywhere within the project area. ${ }^{31}$ One of the Majhis stated, "We heard that the Island is small and close to the sea. But this is not true. It is a big Island like other Islands of Bangladesh. We cannot walk from one end to another. The security forces do not restrict us from moving from one place to another. We sometimes go to the sea to catch fish". ${ }^{32}$ A key informant pointed out that "They would be able to move

\footnotetext{
28 18/11/2020, Key Informant Interview taken at Bhasan Char, Hatiya, Bangladesh.

29 Ibid.

30 Ibid.

31 09/02/2020, Focus Group Discussion taken at Bhasan Char, Hatiya, Bangladesh.

32 09/02/2020, Key Informant Interview taken at Bhasan Char, Hatiya, Bangladesh.
} 
Fig. 5 Medical facilities for the Rohingyas. Source: Photo taken by the research team

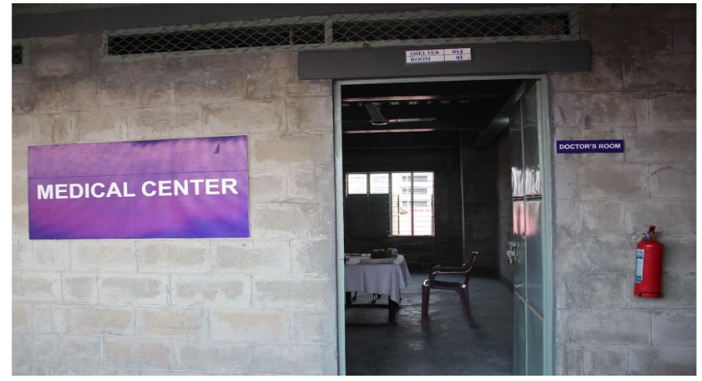

from one cluster to another without any problems." ${ }^{33}$ In case of movement, they will not face any security problems.

Considering the religious sentiment of the Rohingya people, the project planners have constructed mosques and madrasas in Bhasan Char that facilitate their religious rights. The study observed that there are three mosques and a community center located in the middle of the Bhasan Char Ashrayan-3 project. These have enough space to accommodate a large number of people to perform their religious rights. While discussing religious festivals, an informant pointed out that Eid 'Jamaat' (i.e. public prayers) take place each year in Bhasan Char. ${ }^{34}$ Privacy concerns have been taken into account when constructing the housing as the rooms for the families within the concrete-built houses are separated by concrete walls that ensure the families can maintain their privacy.

\section{Discussion}

A key concern of Bhasan Char was associated with environmental hazards and risks (UNHCR 2020; Amnesty International 2020), because there is a widespread perception about the Island as it is composed of sediment which is highly influenced by the monsoon, cyclones and storm surges (Bremner 2020). It is also argued that Islands in Bangladesh are more vulnerable to erosion and floods, as well as being a vulnerable zone for cyclones and storm surges (Haque et al. 2012). The empirical findings and interviews with the professional experts identified that there is not nearly as much apprehension as given by the international organizations and independent researchers thus far. As a riverine and deltaic country, Bangladesh has so many chars and coastal areas where around $25 \%$ of the poor, minority, and displaced people live (Islam 2018). The GoBis struggling to provide adequate opportunities to the people living on the char lands (a landmass surrounded by water bodies), whereas the GoB has arranged good facilities and developed infrastructure for the displaced Rohingya people. Nonetheless, Bangladesh has attained high capacity and set an example to manage its disasters

33 18/11/2020, Key Informant Interview taken at Bhasan Char, Hatiya, Bangladesh.

34 18/11/2020, Key Informant Interview taken at Bhasan Char, Hatiya, Bangladesh. 


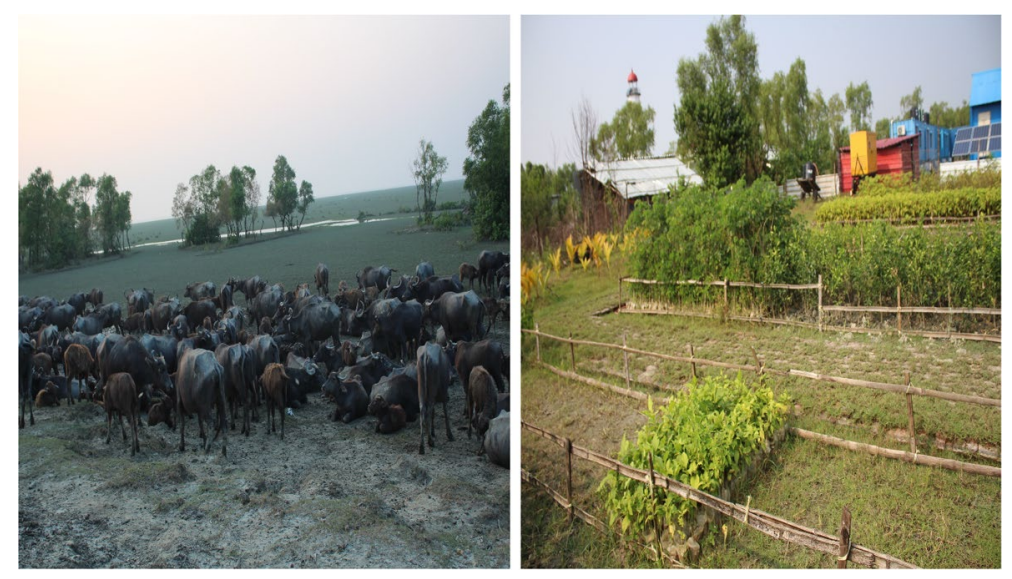

Fig. 6 Livelihood opportunities in Bhasan Char. Source: Photos taken by the research team

and save people (Mallick et al. 2017). Moreover, the country has been successful in tackling frequent disasters and reducing the death toll and damage to property (Haque et al. 2012).

Therefore, it can be argued that Bhasan Char is not such a dangerous place as has been presented by some international organizations, media personnel, and academics. The available infrastructure, services, and resources will help the relocated people to live with safety and security. The KIs, who are working in the project area, have confirmed that housing and other infrastructure are of a high standard and have been built following international standards for the refugees and displaced people (Ullah et al. 2020). The projects contain housing and road facilities as has been prescribed by the international standard of shelter-the minimum shelter space is 3.5 square meter per person (Ullah 2014). In Bhasan Char rooms are 12 feet in length and 14 feet in width and have been built for four people. In terms of facilities and services, the project has the capacity to provide adequate support to the relocated people. Water scarcity in the coastal areas in Bangladesh is a critical issue that is mainly caused by salinity intrusion (Rahman et al. 2017). Keeping this reality in mind, different methods have been adopted to store freshwater during the rainy season. To meet daily household water requirements a water pump system has been installed in the cluster houses.

As a stateless community, the Rohingya people are most likely to be deprived of basic needs and facilities including medical facilities, relief, and educational support (Ullah and Chattoraj 2018). Thus, opportunities for medical, health education, and religious rights have been adequately provided. Rohingya refugees living in the current camps in Cox's Bazar are living in cramped conditions, with poor health facilities, perilous mental health conditions, poor hygiene, and endemic malnutrition, and physical/sexual abuse (Ullah et al. 2020). Keeping this in mind, much attention has been given to ensure their basic needs and services. There have been pilot initiatives for growing foodstuffs, paddy cultivation, cattle herding, and poultry farming, and so on. Exploring these could be viable 
alternatives for a more stable supply of food, and a self-sustaining food supply if relocated people were given access to their production and a supply for their daily sustenance.

However, the sociologist was concerned that good doctors and nurses may not come and live on this Island as it is far from the other parts of Bangladesh. Thus, it was suggested that generous incentives must be given to the medical personnel who would be interested in working on this Island. The international organizations must work and cooperate with the local NGOs and government to provide medical facilities to the displaced people.

Another key concern is the security of the displaced Rohingya people who will be relocated to the proposed Ashrayan-3 project (Hossain 2020). As the displaced people have been severely traumatised due to the persecution and torture they faced in their homeland, adequate security is a must to satisfy their living in the Bhasan Char. One of the key parameters of security was measured by the fact that the Island is under the supervision of the Bangladesh Navy. Nobody would risk the illegal occupation of this place, as it belongs to the GoB; however, worldwide extremist groups may target the Rohingya Muslim people to be involved in terrorist activities (Idris 2017). In this regard, a security expert argued that there is no scope for extremism right now given the security arrangements available there and the active involvement of law enforcement agencies with the project. He further added that,

Rohingya and local criminals are involved in drug dealing in Cox's Bazar.

And the immediate route for this drug is the Rakhine state-the border state of Bangladesh. Thus, the relocation of the Rohingya people to Bhasan Char would cut the connection, and thus reduce the drug and arms business.

In fact, major security concerns matter to the Rohingya displaced people living in the Cox's Bazar camps_-drugs (mainly the drug known as 'yaba'), the arms trade, abduction, killing, and human rights violation. Local people also have great concern regarding the presence of Rohingya displaced people (Yasmin and Akther 2020). Thus, the relocation will reduce the likeliness and prevalence of unlawful activities and the illegal drug business. The presence of the Bangladesh Navy in this area will ensure security as they are dedicated to helping the local people during disasters. Navy ships and patrol boats are always stationed there for any form of emergency.

Indeed, good housing, and physical infrastructure, and livelihood opportunities are key challenges to every host country where large numbers of refugees live (Albakri and Shibli 2019; Ullah et al. 2020). Providing education to the Rohingya children is another challenge for the host country as well as the international organizations (Milton et al. 2017). Some of the already relocated Rohingya people also shared their concern to be together with their relatives living in the Cox's Bazar camps. They want to move and meet with their relatives in Cox's Bazar. It would be a challenge for the host country to allow them to move freely and meet their relatives. Therefore, the international community must come forward to support the Bangladesh government to make the project a successful one for providing better services to the displaced people until their repatriation to their home country. 


\section{Conclusion}

Bhasan Char is not a myth anymore; instead, it is a reality, prepared for temporarily relocating displaced Rohingya people from the camps in Ukhia and Teknaf, Cox's Bazar. The Ashrayan-3 project, which has been prepared for relocating some 100,000 Rohingyas from Cox's Bazar to the Bhasan Char area, needed a quick assessment in terms of understanding its facilities, opportunities, and challenges. Although the government has prioritized this relocation plan due to various existing vulnerabilities Rohingyas have faced in Cox's Bazar camps (e.g. landslides, environmental risks, living in cramped conditions, the pressure of engaging in criminal activities etc.), Bhasan Char has been in the center of discussion for many reasons, including its longevity, sustainability, and opportunities available for people who would be temporarily transferred there. It is often argued that Rohingya people may permanently live in Bhasan Char. Once they are settled there, it would be quite impossible to repatriate them to Myanmar. However, the concerned authority believes that these people will be repatriated to Myanmar. Moreover, the displaced Rohingyas desire to return to their home country with dignity and security.

This paper has presented an assessment of opportunities and challenges for the relocation of the Rohingya displaced people to Bhasan Char. The opportunities for providing better services to the relocated displaced Rohingya people are well developed. Currently, more than fifty national NGOs are coordinating the relief and livelihood programme in the Ashrayan-3 project. The already relocated Rohingya people are happy to receive well-equipped housing facilities and other opportunities in the current location. The young children are happy to have playgrounds, open spaces, and educational institutions. They are not concerned about the uncertainties regarding the future of their repatriation to Myanmar. The Bangladesh government is trying its best to help these displaced people, however, local initiatives seem to be inadequate to manage the large number of Rohingya displaced people living in Bangladesh. The international community must come forward and coordinate with the local NGOs to support the people living in Bhasan Char.

Moreover, further research is also essential in order to get information about the continuous flow of freshwater on the Island because livelihood options (for example, agriculture) are fully dependent on freshwater. The current information about the availability of water is quite not clear of how much water is available in the Island. The study found that measures to tackle the cyclone and flood issues are well developed, but it is suggested that more concrete measures are needed to face any sort of emergencies. The study suggests that eventually these displaced people must be repatriated to their home country Myanmar with adequate safety, security and recognition.

Author contributions All the authors including the corresponding author have equal contribution in this article.

Funding The study received funding and logistic support from the Central Foundation for International and Strategic Studies (CFISS), Dhaka, Bangladesh. 
Data availability The datasets analyzed in this current study are based on qualitative methods which are available from the corresponding author on reasonable request.

\section{Declarations}

Conflict of interest The authors declared that they have no conflicts of interest.

Ethical approval There is no formal ethical approval system in Social Science research in Bangladesh. However, we received consent from the research participants who took parts in the KI interviews and FGDs. We also sought consent from the authority who have been taking care of the Rohingya displaced people in camps in Bangladesh.

Informed consent The study strictly followed the process of informed consent. We received informed consent from the respondents who took part in the FGDs and KIs. We read out the information form before them about the research and informed them that participation in this research is completely voluntary. Moreover, the study did not ask the name and identity of the research participants.

\section{References}

Ahmed I (2020) Special issue on the Rohingya crisis: from the guest editor's desk. Asian J Comp Polit 5(2):85-88. https://doi.org/10.1177/2057891120929570

Amnesty International (2020) Let us speak for our rights: human rights situation of Rohingya refugees in Bangladesh. Amnesty International, London

Alam J (2019) The current Rohingya crisis in Myanmar in historical perspective. J Muslim Minor Aff. https://doi.org/10.1080/13602004.2019.1575560

Albakri TZ, Shibli R (2019) How to improve sustainability: the critical role of education for Syrian refugees. Dev Pract 29(5):662-669

Albert E, Maizland L (2020) The rohingya crisis. Retrieved December 27, 2020, from Council on Foreign Relations: https://www.cfr.org/backgrounder/rohingya-crisis. Accessed 10 Aug 2020

Banerjee S (2020) From Cox's Bazar to Bhasan Char: an assessment of Bangladesh's relocation plan for Rohingya refugees. Observer Research Foundation, Dhaka

Bremner L (2020) Sedimentary logics and the Rohingya refugee camps in Bangladesh. Polit Geogr 77:102-109

Buzan B, Hansen L (2010) Beyond the evolution of International Security studies? Secur Dialogue 41(6):659-667. https://doi.org/10.1177/0967010610388214

Calhoun N (2010) UNHCR and community development: a weak link in the chain of refugee protection? UNHCR Policy Development and Evaluation Service

Chambers R, Conway G (1991) Sustainable livelihood-chambers and conway1991. IDS Discussion paper 296. https://opendocs.ids.ac.uk/opendocs/bitstream/handle/20.500.12413/775/Dp296.pdf?seque nce $=1$. Accessed 20 June 2021

Colantonio A (2009) Social sustainability: linking research to policy and practice. European Commission, Luxembourg City

Döringer S (2020) 'The problem-centred expert interview'. Combining qualitative interviewing approaches for investigating implicit expert knowledge. Int J Soc Res Methodol. https://doi.org/10. 1080/13645579.2020.1766777

Deutsche Welle (2020) Bangladesh Rohingya relocation to isolated Island criticized by rights groups. https://www.dw.com/en/bangladesh-rohingya-relocation-to-isolated-Island-criticized-by-rightsgroups/a-55822366. Accessed 30 Dec 2020

Haidar M (2009) Sustainable livelihood approaches. In: The framework, lessons learnt from practice and policy recommendations. Expert Group Meeting on Adopting the Sustainable Livelihoods Approach for Promoting Rural Development in the ESCWA Region Beirut, pp. 21-22 
Hammerstad A (2014) The securitization of forced migration. In: Loescher G, Long K, Sigona N, Fiddian-Qasmiyeh E (eds) The Oxford handbook of refugee and forced migration studies. Oxford University Press, Oxford, pp 265-276. https://doi.org/10.1177/0967010600031004002

Haque U, Hashizume M, Kolivras KN, Overgaard HJ, Das B, Yamamoto T (2012) Reduced death rates from cyclones in Bangladesh: what more needs to be done? Bull World Health Organ 90(2):150156. https://doi.org/10.2471/BLT.11.088302

Hossain I (2020) After humanitarianism: Bangladesh's evolving rohingya policy. GIGA Focus Asien, Hamburg, p 11

Humanitarian Response (2020) Joint Response Plan: Rohingya Humanitarian Crisis. Humanitarian Response. https://reliefweb.int/sites/reliefweb.int/files/resources/jrp_2020_final_in_design_280220. 2mb_0.pdf. Access 05 Oct 2020

Idris I (2017) Rohingya refugee crisis: impact on Bangladeshi politics. Institute of Development Studies, Brighton

Illius S (2019) An inside look at Bhashan Char-the new home for Rohingyas. https://tbsnews.net/rohin gya-crisis/inside-look-bhashan-char-new-home-rohingyas. Accessed 27 Dec 2020

ISCG (2017) Situation report: Rohingya Refugee Crisis. International Sector Coordination Group, Cox's Bazar

Islam MR (2018) Climate change, natural disasters and socioeconomic livelihood vulnerabilities: migration decision among the Char land people in Bangladesh. Soc Indic Res 136(2):575-593

Islam N (2020) Rohingya: a people under endless Tyranny. Asian Aff Am Rev 48:14

Jacob H (2017) The nowhere people next door: New Delhi should use creative diplomacy to persuade Myanmar to resolve the Rohingya crisis. https://www.thehindu.com/opinion/lead/The-nowhere-people-next-door/article17078540.ece. Accessed 30 Dec 2020

Jacobsen K (2014) Livelihoods and forced migration. In: Fiddian-Qasmiyeh E, Loesche G (eds) The Oxford handbook of refugee and forced migration studies. Oxford University Press, Oxford

Koning J (2001) Social sustainability in a globalizing world: context, theory and methodology explored. In: Proceedings of the UNESCO/MOST meeting, The Hague. National Unesco Commission, Hague, pp. 22-23

Li W, Shuai C, Shuai Y, Cheng X, Liu Y, Huang F (2020) How livelihood assets contribute to sustainable development of smallholder farmers. J Int Dev 32(3):408-429

Majodina DZ (2009) Protection, human rights and forced migration. International conference: 'protecting people in conflict and crisis: responding to the challenges of a changing world'. Refugee Studies Center, University of Oxford, September 2009

Mallick AH (2020) Rohingya refugee repatriation from bangladesh: a far cry from reality. J Asian Secur Int Affairs 7(2):202-226. https://doi.org/10.1177/2347797020938983

Mallick B, Ahmed B, Vogt J (2017) Living with the risks of cyclone disasters in the south-western coastal region of Bangladesh. Environments 4(1):13. https://doi.org/10.3390/environments4010013

McAdam J (2014) Human rights and forced migration. In: Fiddian-Qasmiyeh E, Loescher G (eds) The Oxford handbook of refugee and forced migration studies. Oxford University Press, Oxford

Milton AH, Rahman M, Hussain S, Jindal C, Choudhury S, Akter S, Ferdousi S, Mouly TA, Hall J, Efird JT (2017) Trapped in Statelessness: Rohingya Refugees in Bangladesh. Int J Environ Res Public Health 14(8):942. https://doi.org/10.3390/ijerph14080942

Omann I, Spangenberg JH (2002) Assessing social sustainability the social dimension of sustainability in a socio-economic scenario. In: Paper presented at the 7th Bienniel Conference of the International Society for Ecological Economics, March 6-9, 2002, Tunesia

Rahman MT, Rasheduzzaman M, Habib MA, Ahmed A, Tareq SM, Muniruzzaman SM (2017) Assessment of fresh water security in coastal Bangladesh: an insight from salinity, community perception and adaptation. Ocean Coast Manag 137:68-81

Reliefweb (2020) Press Statement: United Nations Statement on the Relocation of Rohingya Refugees to Bhasan Char. https://reliefweb.int/report/bangladesh/press-statement-united-nations-statement-reloc ation-rohingya-refugees-bhasan-char. Accessed 16 Feb 2021

Srikanth D (2014) Non-traditional security threats in the 21st century: a review. Int J Dev Confl 4(1):60-68

The Daily Star (2020) 40 Rohingyas reach Bhashan Char to visit accommodation project. https://www. thedailystar.net/40-rohingya-refugees-their-way-visit-bhashan-char-project-1956293. Accessed 27 Dec 2020 
The Daily Star (2021) Bhasan char much better than Cox's Bazar camps: UN delegation. https://www. thedailystar.net/rohingya-crisis/news/bhasan-char-much-better-coxs-bazar-camps-un-delegation2103457. Accessed 20 Sept 2021

Uddin N (ed) (2019) Deterritorialised identity and transborder movement in South Asia. Springer, Singapore

Ullah AKMA (2011) Rohingya refugees to Bangladesh: historical exclusions and contemporary marginalization. J Immigr Refug Stud 9(2):139-161

Ullah AKMA (2014) Refugee politics in the Middle East and North Africa. Palgrave MacMillan, London

Ullah AKMA, Chattoraj D (2018) Roots of discrimination against Rohingya minorities: society, ethnicity and international relations. Intellect Discourse 26(2):541-565

Ullah AKMA, Hossain MA, Chattoraj D (2020) Covid-19 and Rohingya refugee camps in Bangladesh. Intellect Discourse 28(2):793-806

UNDP (2005) Human development Report 2005. The United Nations Development Programme, New York

UNDP (2018) Impacts of the Rohingya refugee influx on host communities. United Nations Development Programme, Dhaka

UNHCR (2018) Bangladesh refugee emergency-population infographic. UNHCR-The UN Refugee Agency, Geneva

UNHCR (2020) Press statement: United Nations Statement on the relocation of rohingya refugees to Bhasan Char. https://reliefweb.int/report/bangladesh/press-statement-united-nations-statement-reloc ation-rohingya-refugees-bhasan-char. Accessed 10 Feb 2021

WCED (1987) Our common future. World Commission on environment and development. Oxford University Press, New York

Weis P (1995) The refugees convention, 1951: the Travaux préparatoires analysed, vol 7. Cambridge University Press, London

Wiles R, Crow G, Heath S, Charles V (2008) The management of confidentiality and anonymity in social research. Int J Soc Res Methodol 11(5):417-428

Woodyatt CR, Finneran CA, Stephenson R (2016) In-person versus online focus group discussions: a comparative analysis of data quality. Qual Health Res. https://doi.org/10.1177/1049732316631510

Yasmin L, Akther S (2020) The locals and the Rohingyas: trapped with an uncertain future. Asian J Comp Polit 5(2):104-120

\section{Authors and Affiliations}

\section{Md Rafiqul Islam ${ }^{1}$ (D) Md Touhidul Islam ${ }^{1} \cdot$ Mohammad Shaheenur Alam $^{1}$. Maria Hussain ${ }^{1}$ - Muhammad Mazedul Haque ${ }^{2}$}

Md Touhidul Islam

touhid.pacs@du.ac.bd

Mohammad Shaheenur Alam

shaheen@du.ac.bd

Maria Hussain

maria.hussain@du.ac.bd

Muhammad Mazedul Haque

mmhaqueakash@gmail.com

1 Department of Peace and Conflict Studies, University of Dhaka, Dhaka 1000, Bangladesh

2 Peace Research Institute of Dhaka, Dhaka, Bangladesh 